\title{
PRECEDENT PHENOMENA IN UKRAINIAN POLITICAL DISCOURSE: TYPOLOGY AND PRAGMATICS
}

\section{Siuta H. M.}

\section{INTRODUCTION}

Political discourse is a special area of language and professional activity associated with the process of verbal transmission, the transfer of information from one part of society to another. And even if this transmission is carried out in the format of "subject - subject" ("politician politician", "politician - journalist", "politician - voter"), it still has a socially oriented nature, designed for a wide audience.

Reflections on the issues of structure, communicative organization and pragmatics of political communication led to the formation of a separate linguistic direction - political linguistics. Today, various aspects of this area are actively developing in philology - both abroad (D. Bolinger, A. Burkhardt, W. Dieckmann, TA van Dijk, A. Dörner, H. Girnt, J. Klein, E. Neuland, Th. Niehr, M. Wengeler, V. Bazilev, A. Baranov, V. Karasyk, Y. Karaulov, G. Pocheptsov, O. Sheigal, A. Chudinov, etc.), and in Ukraine (K. Serazhym, O. Zaretskyi, M. Stepanenko, N. Kondratenko, H. Siuta, I. Zavalnyuk, N. Derenchuk, L. Stryi, etc.). At the same time, both foreign and local authors simultaneously use several synonymous and at the same time pragmatically competitive terms to delineate the plane of professional functioning of language: political discourse / discourse of politics, political language /language of politics, political communication, sometimes complementing this row with a somehow more narrow, but still related term political rhetoric.

The purpose of this study is to investigate and describe the typology and pragmatics of precedent phenomena relevant to contemporary Ukrainian political discourse.

\section{Political discourse as a sphere of modern professional verbal communication: system-creating features, current communicative strategies}

The application of communicative-discursive approach gives researchers grounds to define political discourse as a particular manifestation of political communication, which involves the actualization of a political text in a 
communicative act of interaction between a political subject (politician, political force, power) and object (audience, electorate, voter) ${ }^{1}$.

Distinguishing between real and virtual formats of political discourse, O. Sheigal emphasizes that in the real dimension political discourse is "a field of communicative practices as a set of discourse events, it is a current language activity in a certain social space, which is characterized by procedurality and is associated with real life and real time, as well as language creations (texts) that arise as a result of this activity, taken in the interaction of linguistic, paralingual and extralingual factors"2.

It is also worth agreeing that political discourse is an area in which, with the help of correctly chosen linguistic means, political ideas are tested, and key and secondary political messages are verbalized ${ }^{3}$. Therefore, it is important for linguists to focus primarily on the analysis of communicative strategies and language units coordinated with them, as well as to take into account the axiological and evaluative parameters of texts of different genres of political communication, i.e. determined by the communication situation.

Despite the relative "youth" (the beginning of the formation is associated with the declaration of independence in 1991), Ukrainian political discourse today is quite diverse in genre. This multifacetedness is primarily related to the variety of communicative forms (oral and written) and formats of real / virtual communication of politicians with their target audience (speech, debates, interview, press conference, briefing, address, participation in analytical and information TV-programs, political advertising, political slogan, etc.), as well as with a wide range of mechanisms of their sociocommunicative influence. This influence is manifested primarily in the fact that speakers-politicians actively and purposefully appeal to the addressee in order to form in their mind specific ("I" -positive / "opponent" -negative) evaluation and image characteristics of the speaker-politician or political force, provide the desired angle of reception of a specific message about the activities of the speaker-politician or political force in general, alter (strengthen / weaken / overemphasize) already formed ideas about them, recruit a new audience.

Functional extralingual pragmatics of political discourse as a sphere of professional use of language is a struggle for power, a linguistic reflection of the essence of socio-political processes, the activities of a political force, party or individual political or public figure. The specific utilitarian essence

\footnotetext{
${ }^{1}$ Кондратенко Н.В. Український політичний дискурс: Текстуалізація реальності. Одеса : Чорномор'я, 2007. С. 12.

${ }^{2}$ Шейгал Е.И. Семиотика политического дискурса. Волгоград, 2004. С. 21-22.

3 Нагорна Л.Б. Політична мова i мовна політика: діапазон можливостей політичної лінгвістики. Київ : Світогляд, 2005. С. 34.
} 
of texts and statements is determined by the desire of politicians to influence potential audiences: to emotionally incline to their side, to prove the reality of the proposed political program and to convince of the sincerity of the voiced thoughts and intentions. This involves the widest arsenal of linguistic and extralinguistic means, which are subject to the implementation of communicative strategies of argumentation, persuasion, manipulation, etc. Thus, the target audience consciously creates a linguistic picture of the world that will correspond to political interests and goals and provide a particular figure or party with an appropriate level of public (moral and electoral) support ${ }^{4}$. Moreover, such tools are as consistent as possible with the tendency to the use of theatrical political activity, which is also intentionally aimed at attracting public attention ${ }^{5}$.

The information and value area of political discourse is created by professional politicians, journalists and political scientists, and its users, potential and real addresses of transmitted information are also citizens. The activity and mental immersion of citizens in the political sphere depends primarily on the level of democratic development of the state and personal political activity. It is also important to consider the broad historical-cultural and specific temporal-ideological context in order to understand the nature of political discourse.

As N. Kondratenko convincingly demonstrated, the list of basic systemforming features of political discourse defined in O. Sheigal's works (institutionality, dominance of values over facts, semantic uncertainty // phantomism, ideological polysemy, fideism, esotericity ${ }^{6}$ ) needs methodological complementarity with such positions as theatricality, agonality, sacralization, rhetorical character, manipulativeness and dependence on fashion ${ }^{7}$. At the same time, for a relevant description of the linguistic and structural organization of oral and written political texts, it is necessary to pay attention to such their differential features as 1) a vocabulary thematically determined by political activity and 2) a big amount of expressive and influential syntax structures, corresponding to the conditions of professional political communication. It is an area of realization not of rational, but emotional political rhetoric, which is characterized by highly expressive vocabulary, accentuated evaluative

${ }^{4}$ Демьянков В.З. Интерпретация политического дискурса в СМИ. Язык СМИ как объект междисииплинарного исследования. Москва : Изд-во МГУ, 2003. С. 28.

5 Будаев Э.В., Чудинов А.П. Метафора в политическом интердискурсе. Екатеринбург, 2006. С. 11.

${ }^{6}$ Шейгал Е.И. Семиотика политического дискурса. Волгоград, 2000. С. 42-61.

${ }^{7}$ Кондратенко Н.В. Український політичний дискурс: Текстуалізація реальності. Одеса : Чорномор'я, 2007. С. 15, 18, 21. 
characteristics of personalities and activities of politicians, subjectivity of presentation, when it is not logic and facts that are important, but an emotional impact on the audience.

It has already been said above that one of the most expressive systemcreating mental-pragmatic features of political discourse is its manipulativeness. It is motivated by the conscious desire of moderators of political communication to form a predictable perspective of perception, evaluation, interpretation of a phenomenon, event, person, etc., which determines the basic communication strategies of speakers. The tool of this strategy is often a variety of precedent phenomena, which are systematically reproduced in speeches and interviews of politicians of various ranks and function as units of discourse. After all, "appeal to precedent phenomena is a traditional feature of domestic political communication, this technique allows to present the author's political position more vividly, to draw attention to the foundations of modern social theories, to strengthen the pragmatic influence of the text". 8

It is important to emphasize that taking into account the specifics of political discourse encourages researchers to theoretical and methodological derivation of the basic provisions of the theory of precedent, in particular to revise the basic four-component classification of precedent phenomena: precedent name of the person, precedent text, precedent statement, precedent statement, precedent situation ${ }^{9}$. Today it is significantly supplemented by such varieties of precedent phenomena as precedent event, precedent date, precedent name of the object, precedent picture, precedent sound, precedent image $^{10}$. All of them are relevant for professional political communication.

It is also worth emphasizing that the effectiveness of precedent phenomena in political discourse logically corresponds to the defining strategy of conscious-selective perception / response. After all, the reception and interpretation, evaluation of political information, key political messages and accompanying comments usually take place in accordance with the already formed values and information dispositions of the addresses. Therefore, they (those addresses) respond selectively - only to those verbal and emotional stimuli that are most relevant to their expectations. The task

8 Нахимова Е.А. Прецедентные имена в массовой коммуникации. URL: http://www.philology.ru/linguistics2/nakhimova-07a.htm.

9 Красных В.В. Когнитивная база vs культурное пространство в аспекте изучения языковой личности (к вопросу о русской концептосфере). Язык, сознание, коммуникация. 1997. № 1. С. 139.

10 Высоцкая И.В. Спорные вопросы теории прецедентности. Критика и семиотика. 2013. № 1 (18). С. 117-137. 
of precedent phenomena in this case is to accentuate and express the key thesis of the message as much as possible.

The linguistic mentality nature and situational pragmatics of the use of precedent phenomena in the language of politics are generally commensurate with their nature and pragmatics in other types of professional discourses (for example, journalistic, didactic, etc.). First of all, they act as verbal (rarely - audio, visual or syncretic) carriers of intellectual and cultural information important for society, established models of perception and evaluation of historical events or people, monuments of ancient and modern culture, literature, etc. In a sense, precedent phenomena are an expression of the longevity of tradition, and sometimes stereotypes of cognitive-receptive human activity, because they are usually well known to most members of this linguistic and cultural community. In the ideological, manipulative, corporate, mobilization strategies of professional politicians, this criterion, in fact, serves as a motivational basis for the use of specific precedent names, statements, images in a particular communicative situation as potentially resonant, empathic nominative and evaluative means. It is noteworthy that in political communication such a reproduction takes into account the mental structure of modern political space. Its expediency determines the ability or inability to emphasize the key positions of the postulated ideology, political course of the country, party, individual, etc., to transmit or explain behavioral motives or situational intentions to the target audience.

\section{Pragmatics of precedent names in modern Ukrainian political discourse}

One of the most representative types of precedent phenomena in political discourse is precedent names.

As you know, the names of famous people, historical figures, literary heroes, movie characters, etc. are considered precedent in modern linguistics. That is, genetically, these names must be related to a well-known text that belongs to the precedent or to a situation that is well known to native speakers and addressees of the political message. On this basis, D. Gudkov argues that precedent names belong "to the core of linguistic means of recording and transmitting cultural information", materializing "the key concepts of national culture"11. At the same time, Yu. Karaulov emphasizes that the ability of precedent names to accentuate a certain property of an object or phenomenon, to turn it into a generalizedrecognizable feature, makes them related to metaphors. The ideological

${ }^{11}$ Гудков Д.Б. Прецедентное имя в когнитивной базе современного русского (результаты эксперимента). Язык, сознание, коммуникащия. 1998. № 4. С. 82-93. 
derivation of this thesis gives grounds to partially identify precedent names and names-symbols - as universalized language signs, reference verbalizers of certain character traits, physical or psychomental properties, behavioral features, etc .: Моцарт, Ейнштейн - 'a genius', Геракл, Ілля Муромецьь, Вернидуб - 'a person with great physical strength', Iрод - 'a cruel person', Нариис - 'a narcissist', Крез, Абрамович - 'a rich person', Аполлон, Венера, Афродіта, Нефертіті, Ален Делон, Бріджит Бордо 'a man/woman of extreme beauty', Соломон, Сократ - 'a wise man', Дон Жуан, Казанова - 'a seducer, a lover of women', Джеймс Бонд 'a superhero', Мюнхгаузен - 'a braggart', Юда, Павлик Морозов 'a traitor', Отелло - 'a jealous man', Колумб - 'a traveler, discoverer', мати Тереза - 'a kind, merciful woman, protector of the offended', Шерлок Холмс, Пінкертон, міс Марпл - 'a detective', Штірліи - 'a spy', Шумахер - 'a lover of fast driving', etc. For example, Польща зазнала потужного удару інформаційної бомби, отримавши можливість долучитись до таємниць військової розвідки - Військових інформачійних служб (WSI). Минулої n'ятниці президент Лех Качинський своїм указом оприлюднив рапорт з усебічним аналізом діяльності польських «джсеймсів бондів» комуністичного розливу (Україна молода, 22.02.2007); Чому в українській історії так багато мучеників? Тому що в ї політиці багато зрадників. Чому кожне покоління має свого Іуду? (Галичина, 28.07.2009); Тільки огиду може викликати заява В. Медведчука про те, що „УПА не підлягає реабілітації”. Такі слова з уст людини, батько якої був репресований сталінським режимом, змушують згадати витворений радянською пропагандою образ Павліка Морозова (Слово Просвіти, 16-22.03.2006). In the latter example, the precedent name of the historical figure Павлик Морозов (proclaimed a hero by Soviet propaganda as a symbol of honesty and principledness as a young fighter against social injustice; a schoolboy who testified in court against his own father) semantically correlates with the name of the modern politician $\mathrm{V}$. Medvedchuk, actualizing the invariant of the perception of the precedent situation "betraying one's own father / memory of the father" and extrapolating the image of Medvedchuk with negative-evaluation semantics as the one who "sold his own father".

For a complete outline of the corpus of precedent names relevant to modern Ukrainian political discourse, we have to note that there are also such precedent names of place and time: Ельдорадо, Клондайк - 'a place of wealth, excess of something', Канари - 'a place of elite rest', Печерські пагорби, Конча Засnа - 'an elite district / place of work / place of residence'. For example, let us consider the amplitude of the use of the nomination Печерські пагорби, which is relevant to the language of modern 
Ukrainian politicians (ruling and oppositional): як наполягають лідери політичних партій, переважна більшість депутатів будуть представляти у Верховній Раді горезвісні «Печерські пагорби» (npp.com.ua/ articles /articles / personal); Здоровий глузд ... полишив наші політичні печерські пагорби, і ми займаємося здебільшого демагогією, популізмом (www.radiosvoboda.org/con-tent/article/1140196.html); Доморощені цезарі та наполеони час від часу трапляються в багатьох парламентах, але щчоб так часто... Бачили очі, щчо вибирали... Бачили-то бачили, але не дуже й побачиш, коли той цезар чи наполеон раптом вигулькне десь ,,із списку”, мов Пилип з конопель (Урядовий кур'єр, 04.01.2002). These illustrations confirm that the criterion of their recognizability and notoriety remains important for the perception of precedent names included in the political context. Only under this condition can these language signs be adequately decoded. Especially when they are used as a secondary evaluation nomination in the context of the characteristics of a particular statesman, political phenomenon, event or situation.

Verbalization of the modern Ukrainian "political picture of the world" often includes the use of images of children's culture. They are relevant both for the representation of defining lexical and semantic fields (such as "state power", "political struggle", "political propaganda") and for the characterization of Ukrainian politicians (P. Poroshenko, V. Klitschko, V. Yushchenko, L. Kravchuk, L. Kuchma, V. Zelenskyi, D. Razumkov, Y. Tymoshenko, O. Lyashko, Y. Lutsenko, V. Medvedchuk, etc.), political parties, their strategies, results of activity. Precedent names that appeal to the texts of children's literature (Ukrainian and foreign ones), cinema and animation are productive from this point of view.

The popularity of precedent names from the texts of children's literature in the language of politics is associated not only with their recognizability, but also with the cognitive ability to serve as nominative and evaluative models, means of describing psychological and intellectual traits: Незнайко - 'an illiterate or ignorant man', Лис Микита - 'a cunning person'; Фарбований Лис - 'a person who skillfully hides their true nature, successfully adapts to the situation; an imposter'.

Given the manipulative specifics of professional political communication, we focus on the image of Фарбований Лис (precedent text - a fairy tale of the same name by Ivan Franko). It is often used for a sensitive and contemptuous description of statesmen who ideologically mimic to achieve temporary or strategic results of political struggle: Цієї весни 2014 року фарбований лис Олексій Гончаренко став головою передвиборчого итабу Порошенка в Одеській області (Svoboda.2016.22-28.12); Сіромаха з Наикорпусу напосівся на 
фарбованого лиса Садового (https://varianty.lviv.ua/59577/12.02.2019); Кравчука колись у Львові назвали, що він фарбований лис. Таким цей дідуган $і$ залишився. Дуже мала надія, щзо він щось добре зробить для Украӥни (www.pravda.com.ua. 10.08.2020). It is noteworthy that the field of semantic action of this precedent name includes people who are known for the "flexibility" of their political views and behavior - L. Kravchuk, O. Goncharenko, A. Sadovyi.

In precedent texts, the characters of children's literature are clearly differentiated into "positive" and "negative" ones. They usually maintain this connotation in the language of politics, which is motivated by "attempts to give a social positive or negative emotional assessment to those who have influenced and are influencing the political situation in our country"12. From this point of view, the most significant names of the negative fairy-tale characters are Комиій Безсмертний та Баба-яга: Усіх бійців, щзо відбивають напад гнилої імперї, Кощія Балбесовича Безсмертного [V. Putin - H. S.], вітаю з днем Добровольия й Днем нацгвардії (Holos Ukrajini. 29.03.2017); Психологи: Янукович - це Кощій Безсмертний, а Тимошенко - Баба Яга (Корреспондент.net.17.10.2007). Used in reporting on current events in national life, in the contexts-descriptions of political opponents, they consistently implement the seme of "anger", "insidiousness", "aggression" and "cunning".

Another significant aspect of the use of the name Баба Яza in modern political texts is the formula Баба Яга проти ("unfounded, but strongly categorical protest; protest for the sake of protest"), which appeals to the key phrase of a cartoon of the same name: Баба Яга проти - реакиія ватажків ОРДЛО на децентралізацію без особливого статусу (Патріот Донбасу. 14.12.2019); «А Баба Яга - проти!» Сьогодні роль невдоволеної бабиі взяла на себе російська влада в особі Газпрому. Він виявився єдиною зацікавленою стороною, яка виступила проти встановлення європейських правил на пункті з'єднання ГТС Украӥни та Польщі (https://www.facebook.com/NaftogazUA/posts/1300746306671818/ 7.03.2017); Головною новиною тижня став звіт Нідерландів щүодо катастрофи малазійського «Бойнга» на Донбасі минулого року. Результати звіту не задовольнили Російську Федерацію, через що Москва почала свою звичну гру «Баба Яга проти» (https://www.unn.com.ua/uk/news/1511017/16.10.2015).

Reflections on various genres of Ukrainian political communication also clearly demonstrate the use of precedent names of real historical figures and

12 Степаненко М. Публіцистично-політичні перифрази в українській мові. Полтава, 2018. С. 60. 
contemporary local and foreign politicians. However, the strategy of their use is radically different from the re-actualization of names motivated by the texts of literature, cinema or art. Through the names of real (historical or modern) persons, evaluative-cognitive parallels are established with precedent historical, historical-cultural, socio-political situations, which are perceived as carriers of certain meanings and evaluations, connotations. This is in good agreement with the understanding of the purpose of professional political communication - not only to convey basic information, but also to form certain ideas, associations through which the author can influence the addressee of the speech. That is why we regard precedent names in the context of political discourse as minimized arguments. The use of a name as a linguistic sign, a marker of a specific precedent situation implies that the author of an oral message or written text builds the desired connections, which are based on certain associations, comparisons, allusions, thus achieving the necessary understanding in conjunction with the necessary emotional assessment of his speech.

One of the most productive sources of precedent names is history. References to the historical experience of Ukraine, Europe and the world in general represent, for example, comparisons between politicians from different time and countries, such as Юлія Тимошенко - Жанна д'Арк, Маргарет Тетчер. Building such vertical historical-semiotic parallels, the politicians-speakers reconstruct prototype personalities (the national heroine of France, the legendary woman - the long-term effective prime minister of Great Britain), and through them emphasize differential meanings: "ability to self-denial, self-sacrifice for the sake of the people", "incredible efficiency", "efficiency of professional state activity", etc. This simulates the value of the linguistic portrayal of Yulia Tymoshenko as a modern Ukrainian politician.

The maximum degree of such convergence captures the phenomenon of onomastic telescope (contamination, fusion), which is indicative of modern political discourse ${ }^{13}$. In this way such onomatics are formed: Медведчуркіс (Медведчук + Суркіс), Януческу (Янукович + Чаушеску); Путінкович (Путін + Янукович), Путлер (Путін + Гітлер), Медведпут (Медведєв + Путін), Меркозі (Меркель + Саркозі), Меркіавеллі (Меркель + Макіавеллі), Мерколланд (Меркель + Олланд), etc. Such contamination usually reflects a high level of linguistic creativity in expressing an ironic

${ }^{13}$ Колоїз Ж.В. Неузуальне словотворення. Кривий Ріг, 2015. С. 96-104. Див також: Косиченко Е.Ф. Прецедентное имя как средство выражения субъективной оценки: дис. ... канд. филол. наук. Москва, 2006; Стексова Т.И. Словотворчество как проявление политических пристрастий. Сибирский филологический журнал. Новосибирск : Новосибирский гос. пед. ун-т, 2012. 
attitude towards politicians, emphasizing the similarity of their behavior, views, convergence of positions, principles of state formation or foreign policy. For example, Америка підтримала, європейці ні. Тон задали москвофіли Меркозі... Тож у нульових єврозверхники числили Украйну за Росією (Radio Svoboda. 16.04.2014); Медведчуркіс прагне розорити найкращий банк $i$ його вкладників (Українська правда Pravda. 2.10.2003); Ми казали «Меркозі». Але це можна легко перетворити і на «Мерколланд». У иьому випадку навіть відбудеться перерозподіл виливу між Франиією та Німеччиною, - сказав Ернст Штеттер $з$ Фонду європейських прогресивних досліджень (https://ua.euronews.com); Підтримую вимогу Майдану про те, що Янушеску має піти до 10 ранку завтра. Якщо ні, то Майдан піде на штурм. I я теж там буду (twitter.com/ovliashko/status/436950651168628736). According to the communicative-manipulative strategy, such onomastic neologisms contaminated with precedent names create at least two plot-event lines personal and sociopolitical. For example, the above-mentioned anthroponymic innovation of Меркіавеллі, according to researchers ${ }^{14}$, emphasizes that in her internal and external politics, A. Merkel adheres to Machiavelli's principle of the acceptability of any means to achieve political intentions.

Realizing the intention of creating a "thought about...", an effective tool of mental and evaluative manipulation is a contaminated innovation Путлер. Its obvious word-formation connection with the name Гімлер motivates a distinctly negative connotation and correlation with the meaning of "a hater of people"15. For example, Путін хоче української крові. Та чим довще у Донбасі тривають військові дії, гинуть російські солдати, тим більше невдоволення у російському суспільстві. Першими проти кровожерливого Путлера повстали чесні політики Росії. I він вбив Немцова. Це вбивство - вирок Путлеру (Час. 20.03.2015); 31 березня 1 квітня екскерівник ЦРУ $і$ держсекретар США Майк Помпео таємно зустрівся з Кім Чен Ином просто на території КНДР. ... I тепер у путлера зовсім немає друзів - даже Кім його покинув. I путлер зовсім не розуміє, на відміну від Кіма, що йому по-доброму намагалися пояснити американці. Так щзо у світі залишається тільки одна ядерна краӥна-ізгой із їі ізгосм-диктатором - Росія з путлером. I ие дуже погано. Для Росії насамперед (gordonua. 27.04.2018). Numerous repetition of the Путлер nomination (in the title and in-text) models

${ }^{14}$ Цаголова В.А. Прецедентные трансформы (на материале образа А. Меркель в СМИ. Политическая лингвистика. Екатеринбург, 2016.

15 Косиченко Е.Ф. Прецедентное имя как средство выражения субъективной оценки : дис. ... канд. филол. наук. Москва, 2006. С. 212. 
a coherent evaluative model of information presentation, clearly verbalizing the negative attitude towards the politician.

\section{Pragmatics of precedent statements in modern Ukrainian political discourse}

The pragmatics of precedent statements recorded in modern Ukrainian oral and written political texts is multidimensional. First of all, appeals to various genre and thematic precedent texts increase the informativeness and influence of the message of a political figure. After all, the invariants of representations, compactly accumulated, engraved in precedents, allow politicians to transfer a significant amount of information by referring to background knowledge, using minimal means to verbalize it. The same property is associated with a stronger persuasiveness (argumentation) and increased expressiveness, emotionality of political messages, enriched with "the words of others".

The differential function of precedent statements in the language of politics is their argumentative use to confirm opinions and key ideas. Indicative in this regard is the inaugural speech of $\mathrm{P}$. Poroshenko, which, according to experts in strategic communications, has already become a classic in terms of citation appeal to the texts of previous culture. In particular, several vivid quotations unfold and support the evidential modality of the conceptual thesis "Ukraine is Europe". Accordingly, the words Ukraine and Europe are key in the precedent statements by which Poroshenko confirms his opinion on the expediency of Ukraine's European course: Ми, украӥнці, жживий вогник у сім'ї європейських народів $\boldsymbol{i}$ діяльні співробітники європейської цивілізаційної праці». Так казав Іван Франко; "Стояти ногами й серцем на Украйні, свой голови

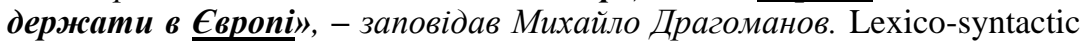
formulas так казав Іван Франко, заповідав Михайло Драгоманов serve as additional markers of argumentativeness and at the same time metaoperators of the call to national authorities.

Argumentation is specifically actualized in situations where politicians hide their communicative or emotional insecurity. The pragmatics of the precedent in this case changes dramatically: the function of accentuating information, confirming, expressing postulated theses becomes peripheral, while the quote forms the emotional resonance of the reported, as it focuses primarily on emotion (feeling), and only then on reason (mind). An illustrative example of such an "argumentatively veiled" citation is in P. Poroshenko's speech delivered after the announcement of the preliminary results of the 2019 elections: Ніколи не здавайся. Ніколи, ніколи, ніколи! Не здавайся в великому, не здавайся в малому, ні в значному, ні в дрібному, ніколи не здавайся, якщо це не суперечить честі $i$ здоровому глузду. Саме цими словами великого британця Вінстона 
Черчіля я керувався завжди... Churchill's words seven repetitions structurally follow the constructive approach of Martin Luther King Jr.'s famous speech "I Have a Dream": the words in the title serve as the leitmotif of the speech and create a meaningful anaphora. At the same time, in the context of a crushing defeat, such a repetition is perceived as a kind of formula for self-affirmation and veiled apology to supporters.

Psycholinguistic motivation of argumentation in the language of politics is reliance on position, statements, already established in the target microsociety as moral authorities. In this case, the politician is aware of the persuasiveness of the citation appeal and counts on it.

It is worth emphasizing the following thesis: in order to have proper argumentative power, a precedent should reflect the value system of the social group, the target audience to which the text is focused, and, if possible, it should be a recognizable formula for verbalizing these values. Such authoritative and potentially recognizable texts include biblical quotations, appeals to the anthem of Ukraine, and classical texts of the Ukrainian literature: Будь-який агресор на кордоні України має згадати Свангельську мудрість: хто з мечем прийде, той від меча $і$ загине! (Inauguration speech of P. Poroshenko); «Душу й тіло ми положим за нашу свободу...» Таку обіиянку ми даємо кожного разу, співаючи Гімн. I рік тому ией рядок припинив бути просто словами. Він став повсякденною дією в боротьбі за иілісність держави $і$ за європейський вибір (P. Poroshenko's address on the occasion of the Day of Dignity and Freedom 21.11.2014); «Я єсть народ, якого Правди сила/ ніким звойована ще не була./ Яка біда мене, яка чума косила! - / а сила знову розцвіла». Ці слова - проникливі, аж мороз шкірою. Із душі та серия великого поета Тичини вони вирвалися 71 рік тому. ... Та вони такі злободенні, ніби сказані прямо сьогодні... (Poroshenko's speech at the parade in honor of the 23rd anniversary of Ukraine's Independence 24.08.2014).

In the case of poor recognition, the role of meta-operators-instructions to the author and the source of expression increases significantly: «Iсторичний факт, - писав Дмитро Донцов у «Підставах нашої політики», - що жодна нація не визволялася лише власними силами. Здійснити їм свої політичні иілі вдавалося лише тоді, коли вони втягали цю справу в круг ідей загальнішого характеру, пов'язували ї̈ з інтересами інших держав». I саме ие зараз ми будемо робити (Extraordinary message of the President of Ukraine to the Verkhovna Rada of Ukraine 27.11.2014); Він (Янукович) не знає української історії. Бо вона для нього - чужа. А хоч би раз зазирнув до підручника, побачив би слова нашого гетьмана Пилипа Орлика. Того самого соратника Івана Мазепи, автора написаної ще триста років тому першої української конституиї: «Народ завжди має право протестувати проти гніту...» (Address of 
the President of Ukraine on the occasion of the Day of Dignity and Freedom 21.11.2014); Актуалізуймо й широко соиіалізуймо слова Довженка: «Якщи любов до Батьківщини - це націоналізм, то я націоналіст» (Слово Просвіти, 17-23.01.2013); Бо вона (інтелігенщія) не забула ще слова митрополита Іларіона: «Кожен народ - то квітка на луці Божім цвітучі» (Літературна Україна, 07.02.2013); У стосунках 3 іншими народами наукою нам будуть слова гетьмана Богдана Хмельницького: “Всі наші зобов'язання ми обов'язково виконаємо, як тільки переконаємося, щзо друга сторона прийме це з вдячністю» (V. Yushchenko's speech on the European Square, 18 вересня 2004 p.); Mu - сдиний украӥнський народ. На Заході і на Сході, на Півночі $і$ на Півдні усім однаково болять бідність $і$ безправ'я. Наш дім не розділиться, бо наме об’єднання, за словами великого Олександра Довженка, “ие кінець дрібному, другорядному і кон'юнктурному (V. Yushchenko's speech on the European Square, 18 вересня 2004 p.); В'ячеслав Чорновіл казав: «Нам потрібні сьогодні реформи, а не революції; сила закону, а не закон сили, ... демократія, а не диктатура» (Extraordinary message of the President to the Verkhovna Rada of Ukraine 27.11.2014). For such contexts the lexical-syntactic development, prevalence of metaoperators is indicative, which does not only introduce a quotation of a historical figure-predecessor into the context, but also provides accompanying, conceptually significant information for this text: слова нашого гетьмана Пилипа Орлика. Того самого соратника Івана Мазепи, автора написаної щее триста років тому першої украӥнської конституиіï.

The second differential communicative-pragmatic feature of the use of precedent statements in the language of professional politicians is manipulativeness.

In the aspect of manipulative operation of precedent statements, it is worth mentioning the demonstrative practice of references to abstract authorities. Its symbolic formulas-metaoperators - як казав хтось із великих...; не пригадую, хто сказав, але... is a sign of lack of convincing arguments, an attempt to avoid a clear affirmative or negative answer, an unambiguous reaction, especially if it is a live communication in the format of debates, discussions, etc.

Controversy is the third significant mental and evaluative dimension of the political use of the precedent. It is a manifestation of an active response to a foreign language, which reveals fundamentally different subjectlinguistic positions of communicators, and the semantics and evaluation of quotations become a kind of starting point for this discrepancy.

According to the modality of response, there are negative (direct denial, principled or moderate discussion), consistent argumentative and invective types of political controversy. 
An example of the fundamental denial of the values of the previous epoch through the precedent statement is contained in the inaugural speech of P/ Poroshenko. Used with sarcasm, the quote Прощай, немытая Россия from the poetry of the same name by $\mathrm{M}$. Lermontov became a kind of slogan of consistent adherence to the European integration course of Ukraine.

The situation of virtual political communication, which has developed in the context of the declared but not implemented Poroshenko-Zelensky election debate, is also clearly ironic. In a correspondence controversy, P. Poroshenko described the absence of his opponent with a line of a humorous folk song "Я прийшов, тебе нема...".

The consistent-argumentative type of polemical modality demonstrates the verbal confrontation between P. Poroshenko and V. Zelensky after a resonant New Year's address to the Ukrainian people, the key thesis of which was instantly axiologized in a transliterated format Какая разніиа? The ideal intellectual and evaluative formula, which reflected the reaction of a large part of the conscious Ukrainian intelligentsia, was T. Shevchenko's quote «Та не однаково мені...». It is the leitmotif of Poroshenko's address on the occasion of the Day of Unity: «Та не однаково мені, / Як Украӥну злії люде / Присплять, лукаві, і в огні / Ї̈, окраденую, збудять.../ Ох, не однаково мені... Флешмобом із циими словами свого пророка Шевченка українці відреагували на лжепророчий заклик "Какая разница?!". Нам не однаково, яка мова, тому щзо украйнська об 'єднує $i$ консолідує. ... Нам не однаково, які пам'ятники. Місиеві громади тепер самі вирімують, як називати вулиці і кому зводити монументи. Нам не однаково, яка церква, і тому ми вибороли Томос. Ми розуміємо, що РПЦ в Україні не просто конфесія, а інструмент геополітичного виливу Росії. Але громадяни вільні обирати свій шлях до Бога...

Studying of the precedent of the language of politics also involves the study of the type of recorded precedent statements depending on the genre of the created text and the specifics of the target audience. Therefore, speeches in foreign state and diplomatic institutions contain numerous philosophical and statist quotes, which are already relevant and recognizable for European politicians, but in Ukraine have not yet become universally precedent: $M u$ пам'ятасмо слова Святого Папи Івана Павла II, який ще напередодні шістдесятої річниці Волинської трагедії казав: «Якщо Бог простив нам у Христі, тоді треба такожс людям віруючим простити взаємні кривди та просити прощення власних провин...» (P. Poroshenko's speech at a joint sitting of the Sejm and the Senate of the Republic of Poland 17.12.2014); Були в намій історї славетні приклади спільних перемог над ворогами. Траплялося й таке, про що не хотілося б згадувати. Але, як сказав хороший друг Украйни і мій, Президент Польщі Броніслав Коморовський, «минуле, навіть найбільш драматичне, не повинно розділяти наші краӥни» (P. Poroshenko's 
speech at a joint sitting of the Sejm and the Senate of the Republic of Poland 17.12.2014); Хочу наголосити, щзо Украӥна відстоює не тільки свою незалежність та територіальну иілісність. Наголошую ще раз: ... Украӥна сьогодні бореться за нашу спільну Європу. I старе гасло набувас нового звучання, змісту та актуальності: Za nasza $i$ wasza wolność! (P. Poroshenko's speech at a joint sitting of the Sejm and the Senate of the Republic of Poland 17.12.2014).

Instead, in "intra-Ukrainian" speeches, the nationally marked quotations from the poems of G. Skovoroda, T. Shevchenko, P. Tychyna, O. Oles, and V. Symonenko serve as intellectual rods: Розповідь про моє бачення «Стратегіï-2020» дозвольте почати з філософії. Як писав Григорій Сковорода у віриі «De libertate»: «зрівнявии все злото, проти свободи воно лии болото" (P. Poroshenko's speech at the press conference "Strategy 2020"); I дозвольте сьогодні застерегти: не чекайте від "Вашингтона з новим праведним законом» якихось позитивних змін. Ми маємо покладатися, в першу чергу, на себе (P. Poroshenko's speech at the press conference "Strategy 2020"); я хотів би згадати слова украӥнського класика Василя Симоненка: «Народ мій є! Народ мій завжди буде! Ніхто не перекреслить мій народ!» (P. Poroshenko's speech at the press conference "Strategy 2020"). The contextual pragmatics of such citation uses is determined by their recognizability and belonging to the core area of the precedent vocabulary, citation thesaurus, formed within the study of the school curriculum in Ukrainian literature.

No less empathetic are the use of quotations that are not part of the core area of the citation thesaurus, but which semantics and tone are as harmonized as possible with the general content and expressive tone of the political message: "Синій, як море, як день - золотий,/ 3 неба і сонця наш прапор ясний», - писав великий украйнський поет Олександр Олесь. Це фарби нашого прапора не лише мирні, але й сильні. Вони - це впевненість! Вони - ие сила! Вони - ие слава! (P. Poroshenko's speech at the ceremony of solemn raising of the State Flag of Ukraine 23.08.2014).

In the structure of modern political texts there are also foreign precedents - ancient maxims, aphorisms of politicians of the twentieth century. $\mathrm{Ha}$ межі минулого та теперішнього століть ми ... добровільно позбулися ядерної зброї. А війна повторно прийшла з тієї сторони горизонту, з якої ї̈, за звичкою, не чекали. Чи не вчили нас ще давньоримські мудреці: "Сі віс пацем, пара беллум" - Хочеш миру - готуйся до війни (P. Poroshenko's speech in honor of the 23rd anniversary of Ukraine's Independence 24.08.2014). 


\section{CONCLUSIONS}

Political discourse is a sphere of professional use of language, in which political processes and events are comprehended, and political ideas are tested. Functional pragmatics of political discourse is a struggle for power, a linguistic reflection of the essence of socio-political processes, the activities of a political force, party or individual political or public figure. Therefore, political texts are an instrument of socio-communication, interaction of a political subject (politician, political force, power) and an object (audience, electorate, voter). The socio-communicative nature of the language of politics is manifested in the fact that speakers purposefully appeal to the addressee in order to form in their mind specific ("I" -positive / "opponent" - negative) evaluative and image positions on the activities of the speaker-politician or political force.

One of the most pronounced system-creating mental-pragmatic features of political discourse is manipulativeness. A variety of precedent phenomena become a tool of manipulativeness, which are systematically reproduced in speeches and interviews of politicians of various ranks and function as units of discourse.

The linguistic nature and situational pragmatics of the use of precedent phenomena (names and statements) in the language of politics are commensurate with their nature and pragmatics in other types of professional discourses. They act as verbal carriers of intellectual and cultural information important for society, established models of perception and evaluation of events, people and more. One of the main criteria for the use of precedent names and statements as potentially resonant, empathic nominative and evaluative units of political communication is their recognizability.

The main aspects of the pragmatics of precedent phenomena in political discourse are argumentativeness, manipulativeness and polemics.

The prospect of studying the typology and pragmatics of precedent phenomena in modern Ukrainian political discourse is determined by the possibility of in-depth study by comparing them with units in the texts of other professional discourses.

\section{SUMMARY}

Political discourse is an area of language and professional activity, related to the comprehension and verbalization of information about political processes and events and the constant transmission of this information to society.

Linguopragmatics of political discourse is a linguistic reflection of the processes of struggle for power and activities of political forces and parties subordinate to this struggle. Socio-communicative nature of the language of politics manifests itself in the fact that speakers appeal to the addressee in order to form in their mind specific ("I" -positive / "opponent" -negative) 
evaluative-image positions. To do this, they use a wide arsenal of language tools, aimed at implementing strategies of argumentation, persuasion, manipulation, and polemics. A variety of precedent phenomena becomes a tool of these strategies.

The most representative varieties of precedent phenomena in political discourse are the precedent names and statements. They act as verbal carriers of intellectual and cultural information, established models of perception and evaluation of events, people, etc. Therefore, using them for verbalization of lexical and semantic fields (e.g., "state power", "political struggle") and for characterization of politicians, political parties, their activities and its results is pragmatically justified.

Differential functions of precedent phenomena in the language of politics are:

1) argumentativeness (confirmation / refutation of one's own opinion) by relying on someone else's, already established as a moral and value axiom);

2) manipulativeness ("adaptation" of "the words of others" to a specific socio-communicative situation, accompanied by obvious or hidden change of primary semantic and evaluative meanings);

3 ) polemics (active response to the opponent's speech, which reveals the difference of positions; the quote becomes a means of emphasizing this discrepancy).

Prospects for the study of the typology and pragmatics of precedent phenomena in the Ukrainian political discourse determines the possibility of their in-depth study in comparison with the same units in texts of other professional discourses.

\section{REFERENCES}

1. Будаев Э.В., Чудинов А.П. Метафора в политическом интердискурсе. Екатеринбург, 2006.

2. Высоцкая И.В. Спорные вопросы теории прецедентности. Критика и семиотика. 2013. № 1 (18). С. 117-137.

3. Горбань В.В. Креативный потенциал антропонимов в политическом дискурсе (изменчивость vs устойчивость). Слов'янський збірник. 2014. № 18. С. 20-28.

4. Гудков Д.Б. Прецедентное имя в когнитивной базе современного русского (результаты эксперимента). Язык, сознание, коммуникация. 1998. № 4. С. 82-93.

5. Гудков Д.Б. Прецедентные феномены в текстах политического дискурса. Язык СМИ как объект междисциплинарного исследования. Москва, 2010. С. 141-161.

6. Демьянков В.3. Интерпретация политического дискурса в СМИ. Язык СМИ как объект междисииплинарного исследования. Москва : Изд-во МГУ, 2003. С. 116-133. 
7. Ковальова О. Політичний дискурс: сучасні лінгвістичні інтерпретації. Актуальні питання гуманітарних наук. Вип. 27, Т. 2, 2020. C. 101-107.

8. Колоїз Ж.В. Неузуальне словотворення. Кривий Ріг, 2015.

9. Кондратенко Н.В. Український політичний дискурс: Текстуалізація реальності. Одеса : Чорномор'я, 2007.

10. Кондратенко Н., Стрій Л., Билінська О. Лінгвопрагматика політичного дискурсу: типологія мовленнєвих жанрів. Одеса, 2019.

11. Косиченко Е.Ф. Прецедентное имя как средство выражения субъективной оценки: дис. ... канд. филол. наук. Москва, 2006.

12. Красных В.В. Когнитивная база vs культурное пространство в аспекте изучения языковой личности (к вопросу о русской концептосфере). Язык, сознание, коммуникация. 1997. № 1. С. 128-144.

13. Нагорна Л.Б. Політична мова i мовна політика: діапазон можливостей політичної лінгвістики. Київ : Світогляд, 2005.

14. Нахимова Е.А. Прецедентные имена в массовой коммуникации. URL: http://www.philology.ru/linguistics2/nakhimova-07a.htm.

15. Стексова Т.И. Словотворчество как проявление политических пристрастий. Сибирский филологический журнал. Новосибирск : Новосибирский гос. пед. ун-т, 2012.

16. Степаненко M.I. Публіцистично-політичні перифрази в українській мові: 2017. Полтава, 2018.

17. Цаголова В.А. Прецедентные трансформы (на материале образа А. Меркель в СМИ. Политическая лингвистика. Екатеринбург, 2016. C. 208.

18. Шейгал Е.И. Семиотика политического дискурса. Волгоград : Перемена, 2004.

\section{Information about the author:} Siuta H. M.,

Doctor of Philological Sciences, Professor, Senior Research Officer at the Department Stylistics,

Language Culture and Sociolinguistics

Institute of the Ukrainian Language of the National Academy of Siences of Ukraine 4, Hrushevskoho str., Kyiv, 01001, Ukraine 